音楽の統語処理に及ぼすバス旋律の効果 ${ }^{1}$

石田 海 (大阪大学大学院人間科学研究科)

池田 一成 (東京学芸大学教育学部)

入戸野 宏 (大阪大学大学院人間科学研究科)

\title{
Effect of a Bass Voice Melody on Syntactic Processing of Music
}

\author{
Kai IsHIDA (Graduate School of Human Sciences, Osaka University) \\ Kazunari IKeDA (Faculty of Education, Tokyo Gakugei University) \\ Hiroshi NitTono (Graduate School of Human Sciences, Osaka University)
}

\begin{abstract}
The early right anterior negativity (ERAN) is an event-related potential occurring when a chord in Western tonal music deviates from the tonal context, which is considered to reflect syntactic processing of music. A recent study reported that the ERAN was enhanced when pitch deviance occurred in a part of the main melody, rather than other parts. However, it remains unclear whether this effect was caused by deviance in the main melody or the treble voice because only a soprano voice was used as the main melody. We used a bass melody in the current study and compared the ERAN amplitudes between bass-deviant and soprano-deviant chords. The results indicated that a larger ERAN was elicited by a chord with soprano-voice deviance than a chord with bass-voice deviance, suggesting that in syntactic processing of music, the treble voice effect is dominant than the melody effect.
\end{abstract}

Key words: event-related potential, early right anterior negativity, syntactic processing of chord, main melody, music perception

\footnotetext{
2020.6.26受稿, 2020.10.15受理, 2020.10.24 J-STAGE早期公開, doi: 10.5674/jjppp.2008br

連絡者及び連絡先：テ565-0871 大阪府吹田市山田丘 1-2 大阪大学大学院人間科学研究科 入戸野 宏

E-mail: nittono@hus.osaka-u.ac.jp

1 この論文の審査は機関誌編集副委員長が担当し, 著者である編集委員長 (入戸野 宏) は審査や採否の判断にまったく関

与していない。
} 
【要 約】右前頭部初期陰性電位 (early right anterior negativity: ERAN) は, 西洋の調性音楽において調性的文 脈から逸脱した和音が提示されたときに生じる事象関連電位である。ERANは, 音楽の統語処理を反映すると考 えられている。近年の研究で, ピッチ逸脱が主旋律に生じたときは, 他の声部に生じたときよりもERANが増大 すると報告された。しかし，その研究はソプラノの主旋律のみを検討していたため，この効果が主旋律の逸脱に よるものか, 高音声部の逸脱によるものかは明らかでない。本研究ではバス主旋律の刺激を用いて, ソプラノが 逸脱する和音とバスが逸脱する和音に対するERAN振幅を比較した。その結果, ERAN振幅は, ソプラノ声部が 逸脱するときにバス声部が逸脱するときよりも大きかった。これは, 音楽の統語処理において, 高音声部の効果 が主旋律の効果よりも優勢であることを示唆している。

私たちが日常的に耳にする音楽は，多くが旋律 (melody)，和音 (chord) およびリズム (rhythm)に よって構成されている。旋律は目立って耳なじみがよ いが，その背景にある和音も音楽の緊張感を方向づけ る役割を担っている (Meyer, 1956)。このように，旋 律と和音は相互に関係して処理されることがある (Thompson, 1993)。

西洋の調性音楽を聴取すると, 和音系列から中心音 （その系列が属する調の主音。たとえば，八長調だと ド $/ \mathrm{c}$ ）が抽出され, 特定の調に基づく調性文脈が形 成される (Bharucha \& Krumhans1, 1983)。調性文脈 の下で，和音は緊張を高めたり緩和したりする機能を 示す。その文脈でさまざまな和音を規則に従って階層 的に配置したものが音楽の統語構造である (Ma et al., 2018)。音楽を聴くときは，この構造に基づいて次の 和音への予期が生じる。たとえば, I度の和音 (八長 調ではドーミーソ/c-e-g) は, 緊張を緩和し, 終止位 置に置かれると高い安定感を示す和音である(トニッ ク機能の和音)。また, $\mathrm{V}$ 度の和音 (八長調ではソシーレ $/ \mathrm{g}-\mathrm{b}-\mathrm{d})$ は, 緊張を高め, トニックへ落ち着こ うとする強い動機を持った和音である（ドミナント機 能の和音)。さらに, IV 度の和音 (ハ長調ではファーラ ード／f-a-c）は，ドミナントよりも緊張が低いが安定 感が弱く, 安定した和音であるトニックに緩やかに落 ち着こうとする動機を持つ(サブドミナント機能の和 音)。 $\mathrm{V}$ 度の和音の後には, I度の和音が提示されるの が最も自然なので，そこにサブドミナント機能の和音 が提示されると，予期とのミスマッチが起こる。この 音楽的な規則から逸脱した和音を検出したときに惹起 される神経活動が, 事象関連電位 (event-related potential: ERP) の右前頭部初期陰性電位 (early right anterior negativity: ERAN) である (Koelsch et al.,
2000, 2002, 2007; Leino et al., 2007)。この陰性電位は, 潜時およそ $100 \mathrm{~ms}$ から生じ， $150-200 \mathrm{~ms}$ 付近でピー クを迎える (Koelsch et al., 2000; Koelsch \& Sammler, 2008; Pagès-Portabella \& Toro, 2020)。先行研究で は, 調性文脈からの逸脱として, その調の音階に属さ ない音を含む和音 (たとえば, ドッペルドミナント。 サブドミナントと代替可能な機能を持ち，八長調では

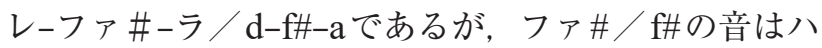
長調の音階には含まれない) を提示するとERANが生 じることが明らかになっている (Koelsch et al., 2007)。これに加えて，その調の音階に含まれる音だ けで構成された和音であっても, 配置規則から外れた 系列位置に提示されるとERANが生じる (Koelsch et al., 2007; Koelsch \& Jentscke, 2008)。たとえば, ド ミナントの和音 ( $\mathrm{V}$ 度の和音) の後にはトニックの和 音 (I 度の和音) が強く予期される。そこにII度の和音 (ハ長調ではレーファーラ/ d-f-aでハ長調の音階構成 音) が提示されるとERANが生じる (Koelsch et al., 2007; Koelsch \& Jentscke, 2008)。これは, II度の和 音がトニックではなくサブドミナント（IV度の和音） の機能を果たすからである。

一方，同一の調に属する音を継時的につなぎ合わせ て構成した調性的にまとまりのよい旋律では，その調 の主音 (八長調では, ド / c) による終止が強く期待さ れる (阿部 - 星野, 1985; 星野 - 阿部, 1984)。旋律 の文脈においても, 先行して提示された音列から抽出 されるその調の主音に基づいて, 文脈的な予期が形成 される。このように，和音の調性だけでなく旋律の調 性に関しても統語処理が行われている可能性があり, その可能性は行動研究だけでなく神経生理学的研究で も示唆されている (Brattico et al., 2006; Koelsch \& Jentschke, 2010; Miranda \& Ullman, 2007)。 
Kim et al.(2014)は, 4声部から成るホモフォニー 的な和音系列を用い, その終止和音で主旋律声部が逸 脱していると, 主旋律以外の声部が逸脱していたとき と比較して, ERANに相当する脳磁図反応が大きく なることを示した。 Kim et al.は, この結果に基づい て, 主旋律は音楽の統語処理において顕著な役割を 担っていると主張した。しかし, Kim et al.が用いた のはソプラノ声部が主旋律の刺激のみである。4声 (ソプラノ, アルト, テノール, バス)の音楽刺激で は,ソプラノは最高声部にあたる。得られた結果は, 主旋律が逸脱したためではなく, 物理的に顕著な高音 声部が逸脱したために生じた可能性もある。Fujioka et al. (2005, 2008)は，2声部により構成された刺激に おいて, 高い音域の旋律が最終音でピッチ逸脱する と, 低い音域の旋律が最終音でピッチ逸脱する場合に 比較してより大きなミスマッチ陰性電位 (mismatch negativity: MMN) が生じることを示した。この現象 は高音声部優勢効果 (high-voice superiority effect; Marie et al., 2012) とよばれる。Fujioka et al.(2005) は, 高音が感覚記憶表象の段階ですでに優勢に処理さ れると述べている。

本研究では, 音楽の統語処理に対する主旋律の効果 を，ソプラノではなくバス声部に主旋律がある4声 (ソプラノ，アルト，テノール，バス）の音楽刺激を 用いて検討した。刺激は4声で和音が進行するが, 特 定の声部が旋律的な輪郭を持ち, その他の声部が和声 的に伴奏をするホモフォニーの形態であった。具体的 な検討方法として, ともに調性文脈から逸脱した和音 であるが, 主旋律 (バス) 声部がピッチ逸脱した終止 和音と, その他の声部がピッチ逸脱した終止和音に対 するERAN振幅を比較した。終止位置は, 最も文脈 的期待が高まる部分であり, 高い安定感を示すトニッ クの和音が予期される。本研究では, それとは違った サブドミナントの和音を提示することによって ERANを測定した。

主旋律のあるバス声部が逸脱する終止和音に対し て, ソプラノ声部が逸脱する終止和音よりも大きな ERANが生じた場合, 冕脱和音の統語処理に対する 主旋律の効果が高音声部の効果よりも大きいといえ る。反対に, ソプラノ声部が逸脱する終止和音に対し て, 主旋律のあるバス声部が逸脱する終止和音よりも 大きなERANが生じた場合, 高音声部の効果が主旋
律の効果よりも大きいといえる。

\section{方 法}

実験参加者 $\quad 19-23$ 歳 $(M=21.4, S D=2.4)$ の 11名 （女性10名, 男性 1名) が実験に参加した。すべての 参加者は, 大学または個人で専門的な楽器のレッスン を $11-20$ 年間 $(M=16.1, S D=5.9)$ 受けている学生で あった。標準純音聴力検査を行い, 聴力が正常である ことを確認した。利き手の検査 (Oldfield, 1971)を 行ったところ，9名が右手利き，2名が左手利きで あった。実験開始前に, 参加者全員に書面と口頭で実 験内容について説明したうえで了解を得て, 同意書に 署名をしてもらった。実験終了後には謝金を渡した。 本実験は, 東京学芸大学の研究倫理審査委員会の承諾 のもと行われた。

刺激 Figure 1 に, 本研究で用いた和音系列の例を 示す。刺激は楽譜作成ソフトウェアFinale (MakeMusic社) を用いて作成し，ピアノの音色で提 示した。4声（ソプラノ, アルト, テノール, バス) か ら成るバス主旋律の3 小節の系列で, 4/4拍子, 200 bpmとした。四分音符で1拍につき $300 \mathrm{~ms}$ であり, 休符も含めた系列全体の提示時間は $3,600 \mathrm{~ms}$ であっ た。系列は主旋律声部を含めた4声の和音で進行する ホモフォニーで $(\mathrm{I} 1 \rightarrow \mathrm{IV} 1 \rightarrow \mathrm{II} 1 \rightarrow \mathrm{V})$, 最後はトニック の機能を持つI度の和音での終止が予期される構造と

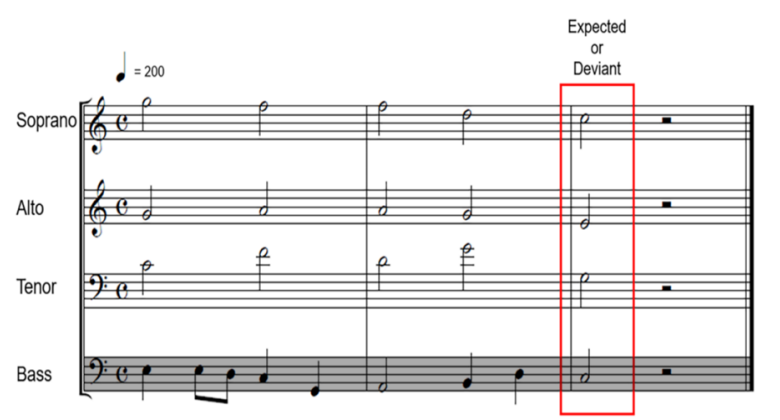

Figure 1. A sample of a chord sequence used in the experiment. The bass part played the main melody. There were five types of deviant chords, and each had pitch deviances in different voice parts: B (bass), TB (tenor and bass), SAT (soprano, alto, and tenor), ATB (alto, tenor, and bass), and SATB (all voice parts). All the deviant chords were the chords on the second scale degree with subdominant function. 
した。終止和音を6種類に操作した。先行文脈から予 期される和音 $(p=.375)$ と逸脱した 5 種類の和音 (そ れぞれ $p=.125)$ であった。逸脱和音は, バス声部の みピッチ逸脱する $\mathrm{B}$, バスとテノールの声部がピッチ 逸脱する $\mathrm{TB}$, ソプラノとアルト, テノールの声部が ピッチ逸脱するSAT, アルトとテノール，バスの声部 がピッチ逸脱するATB, 4声部すべてがピッチ逸脱す るSATBであった（楽譜は付録参照。サンプル音源は https://osf.io/gdexw/から試聴できる)。いずれの逸脱 和音も調文脈に含まれる音で構成されるが，サブドミ ナントの機能を代替できる和音 (II 度の和音) であっ た。系列最終位置におかれたII度の和音に対して ERANが出現することは過去の研究で示されている (Koelsch et al., 2007; Koelsch \& Jentschke, 2008)。

さらに，予期される和音で終止する系列 $(p=.375)$ のうち，3分の1でバスの音色逸脱が生じ， 3 分の 1 で ソプラノの音色逸脱が生じるようにした。音色逸脱は 終止音以外で生じた。これらの刺激は, 後述する音色 逸脱検出課題で主旋律に注意を向けさせる目的で用い た。

作成した $8 つ の$ 系列（予期される和音 1 , 逸脱和音 5 , バス音色逸脱 1 , ソプラノ音色逸脱1）を12の長調に転 調し ${ }^{2}$, 計96刺激を準備した。なお, 実験では, バス 主旋律だけでなくソプラノを主旋律とした条件を異な るブロックに扔いて実施したが, 刺激の設定に不備が あったため，本論文では報告しない。

装置 作成した刺激はメロンテクノス株式会社の音 刺激システムMT-ST-Sによって出力され, ヘッド フォン（Elega製DR-531）によって左右 $60 \mathrm{~dB}$ SPLで 提示された。脳波測定にはメロンテクノス株式会社の 事象関連電位／反応分析ツールEFRP-ERPを使用し た。

手続き 実験は防音室内で個別に行い，2日間に分 けて実施した。転調した12種類の調ごとにブロック を分け，計12ブロックを実施した。各ブロックでは 1 つの和音系列を 1 試行とし， 8 種類の系列をランダム な順序で提示した。試行間間隔は $100 \mathrm{~ms}$ であった。

\footnotetext{
2 本研究で用いた音源は 12 平均律をもとに作成し，転調し た 12 の長調は「八長調, 変二長調 (嬰八長調), 二長調, 変ホ長調 $($ 嬰二長調 $)$, 小長調, へ長調, 変卜長調 (嬰へ 長調), 卜長調, 変イ長調, イ長調, 変口長調, 口長調」 に対応する。
}

12 長調の提示順は実験参加者間でランダム化した。 各ブロックは実験参加者のペースで開始し，8種類の 和音系列がすべて 10 回以上提示されるまで続いた。

主旋律に意図的に注意を向けさせるため, 音色逸脱 検出課題を行った。主旋律 (バス) の音がピアノの音 色からチェンバロの音色に変わったときにボタンを押 すように求めた。主旋律以外 (ソプラノ) の音の音色 変化は無視させた。終止和音の逸脱については言及し なかった。

各主旋律条件において12ブロック実施したため, 実験全体の刺激提示時間はおよそ168分であった。各 日に，各主旋律条件から6調分（合計12ブロック）を ランダムに選択して提示した。電極設置なども含め て，2日間の実験に要した合計時間は約6時間であっ た。

記録および分析 脳波は, $\mathrm{Ag} / \mathrm{AgCl}$ 電極を用い, 国際式10-20法に基づく7部位 (F7, F8, F3, F4, Fz, $\mathrm{Cz}, \mathrm{Pz})$ と右耳架から導出した。基準電極は左耳架と し，記録後に両耳架平均で再基準化を行った。瞬きや 眼球運動を監視するために, 左右眼角外と右眉上, 右 眼窩下縁に電極を置き, 水平・垂直眼電図を記録し た。脳波と眼電図は通過周波数 0.16 - $63.3 \mathrm{~Hz}$ で記録 した。サンプリング周波数は $500 \mathrm{~Hz}$ とし, 電極イン ピーダンスは $10 \mathrm{k} \Omega$ 以下とした。

記録した脳波および眼電図は, Brain Vision Analyzer 2.0 (Brain Products, Germany) を用いて分析した。波形 には高帯域遮断 $30 \mathrm{~Hz}$ のフィルタをかけ, 加算平均区間 は刺激提示前 $200 \mathrm{~ms}$ から刺激提示後 $600 \mathrm{~ms}$ とした。 $\pm 80 \mu \mathrm{V}$ 以上の電位を含む区間は加算平均の対象から 除外した。

音色逸脱試行については, 逸脱後 $200 \mathrm{~ms}$ から $1,000 \mathrm{~ms}$ な゙のボタン押しを計測した。音色逸脱試 行はERP分析から除外した。

ERANは，逸脱和音に対するERP波形から予期さ れた和音に対する $\mathrm{ERP}$ 波形を引算した差分波形上で 検討した。ERAN振幅は130-180 ms の区間平均電 位として求めた。本実験の ERANは左右差を示さず 前頭部に一様に広がっていたため, 分析には前頭部 5 部位 $(F 7, F 3, F z, F 4, F 8)$ の平均值を用いた（部位を含 めた分析については付録参照)。ERANが出現してい るかどうかを検討するために，各逸脱和音と予期され た和音のペアについて 130-180 msの区間平均電位 
を対応のある $t$ 検定 (片側検定) で比較した。5つの検 定を行うため, Bonferroni法による $p$ 值の調整を行っ た。また, 高音声部の逸脱効果と主旋律の逸脱効果を 比較するため, SATと ATBの ERP差分值について対 応のある $t$ 検定 (両側検定)を行った。

\section{結 果}

操作チェック 主旋律に㧍ける音色逸脱の検出率は 平均 $89.6 \%(S D=8.7)$, 反応時間は平均 $673.8 \mathrm{~ms}(S D$ =70.8)であり, 参加者はバス声部に注意を向けてい たといえる。ソプラノ声部に生じた音色逸脱に対する フォールスアラーム率は平均 $2.2 \%(S D=3.4)$ であっ た。

事象関連電位 各刺激条件の平均加算回数は 99.1 回であった(範囲57-136)。Figure 2に，元のERP 波形と, 逸脱和音から予期された和音を引算した差分 波形を示す。差分波形上でのERANは $160 \mathrm{~ms}$ 付近に ピークがあった。また，予想しなかったことである が，バス声部のみが逸脱した和音 (B)には，200 ms 付近でピークを迎える除性電位N2がみられた。

Figure 3 に, 逸脱刺激ごとのERAN振幅を示す。 ERANが出現していたかを確認するため $t$ 検定を行っ たところ, TB, SAT, SATBの逸脱刺激でERANが有 意に出現していた, $t \mathrm{~s}(10)>3.26, p<.05$ (Bonferroni法 による調整後)。次に, SATと ATBのERP差分值につ いての対応のある $t$ 検定を行ったところ，SATがATBよ りも有意に陰性であった, $t(10)=2.47, p=.033$ 。

Bに対して生じた陰性電位N2について200$250 \mathrm{~ms}$ の区間の平均振幅を求め, 5 水準 (B, TB, SAT, ATB, SATB) の 1 要因反復測定分散分析を行ったとこ 万, 逸脱和音の主効果が有意であった， $F(4,40)=$ 12.12, $p<.001$, Huyhn-Feldt $\varepsilon=1.00, \eta_{\mathrm{p}}^{2}=.55$ 。多重 比較の結果, $\mathrm{B}$ は TB 除く各逸脱に比べて有意に陰 性であった, $p<.05$ (Bonferroni法による調整後)。

\section{考 察}

本研究は, バス声部が主旋律である和音系列の終止 和音に対する統語処理が, 低音声部（旋律のあるバス 声部) と高音声部 (伴奏声部の一部) の逸脱のどちら に強く影響されるかを明らかにすることを目的とし
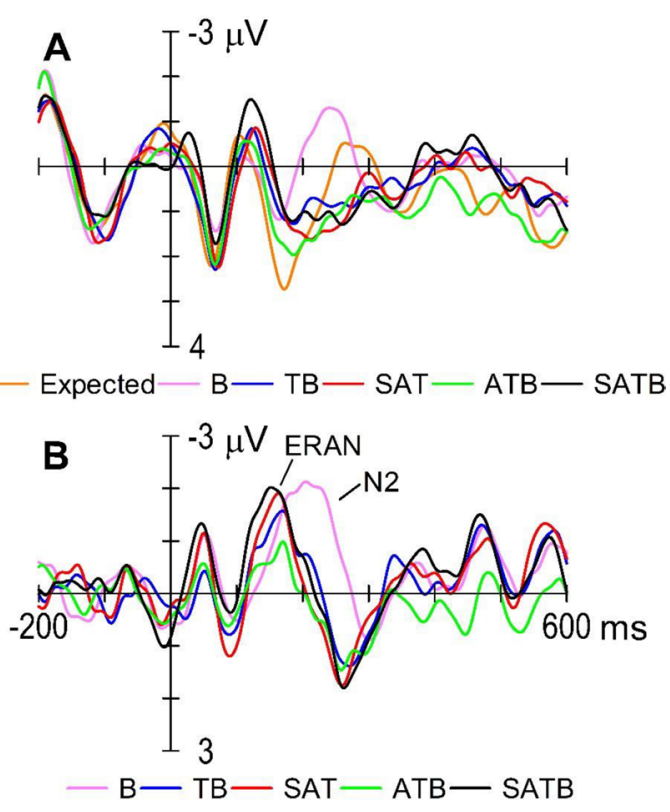

Figure 2. Grand average ERP waveforms (mean of the five frontal electrodes: F7, F3, Fz, F4, and F8). (A) Original ERP waveforms elicited by the six types of terminal chords. (B) Deviant minus expected difference waveforms for the five types of deviant chords.

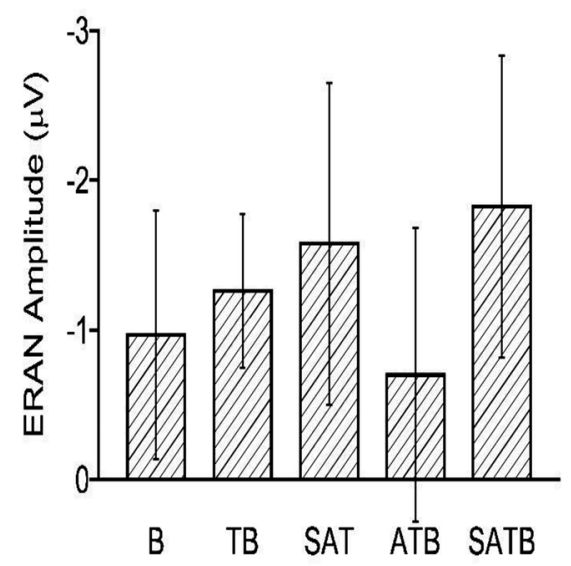

Figure 3. The mean ERAN amplitudes over the five frontal electrodes in the time window of 130-180 ms. The error bars indicate $95 \%$ confidence intervals.

た。その結果, 主旋律であるバス声部が逸脱した刺激 よりも，ソプラノ声部が逸脱した刺激に対して，より 大きなERANが生じ, 音楽の統語処理に対する高音声 部の効果が強いことが示された。また，バスだけが逸 脱した和音に対して, 他の刺激で生じた陰性よりも遅 く, $200 \mathrm{~ms}$ 付近で陰性のピークを迎える $\mathrm{N} 2$ が生じた。 Kim et al.(2014)は, 主旋律がソプラノ声部にある 
和音系列を用いた実験において, ソプラノ声部が逸脱 した和音に対して大きなERANが生じたことから， 主旋律が音楽の統語処理に影響すると述べた。しか し, 主旋律がバス声部にある和音系列を用いた本研究 では, 主旋律がピッチ逸脱した和音よりも, ソプラノ 声部がピッチ逸脱した和音に対してょり大きな ERANが生じた。このことは，ERANに反映される 統語処理においても, 高音声部優勢効果 (Marie et al., 2012) が存在する可能性を示している。音楽の統語処 理は, 音楽の知識にもとづく調性の表象に完全に依存 するものではなく，ピッチの高低などの物理的特性に も影響を受けるのかもしれない。ERANはFujioka et al. $(2005,2008)$ が高音声部優勢効果を示したMMN とは性質が異なる。音楽的な知識を必要としない規則 性からの逸脱や物理的逸脱を反映する陰性電位が MMNである (Koelsch, 2009)。一方, 音楽的規則に ついての潜在的知識（日常的な聴取などによって獲得 される) に基づく調性的予期からの逸脱の検出を反映 する陰性電位がERANである (Koelsch et al., 2007)。 本研究では, Koelsch \& Sammler(2008)にならい, 終止和音に含まれる音はすべて先行文脈において最低 1 回は出現させた。そのため, 本研究で生じた陰性電 位は, 物理的に新奇な音に対する反応ではないといえ る。

本研究では, 音色逸脱検出課題を実施したことによ り, 実験参加者は主旋律に選択的に注意を向けた状態 で音楽を聴取していた。ERAN振幅に与える注意の効 果として, 注意を向けていないときはERANが出現し なかったという報告や (橋本, 2011), ERANの振幅が 減少したという報告 (Loui et al., 2005; Maidhof \& Koelsch, 2011) がある。本研究のように, バス主旋律 に意図的に注意を向けている状況でもソプラノ声部の 逸脱効果が大きかったことは, 音楽の統語処理に与え る高音声部の影響が強いことを示している。しかし， 実際の音楽聴取場面では, 意図的に特定の声部に注意 を向け続けることはほとんどない。これまでERAN の計測に使われてきた音楽を聞き流す状況においても 同様の効果が得られるかどうかは, 今後の検討が必要 である。

本研究において生じたERANの頂点潜時は, 先行 研究で生じたERAN (Koelsch \& Jentschke, 2010; Koelsch \& Sammler, 2008; Pagès-Portabella \& Toro,
2020)よりも約 $30 \mathrm{~ms}$ 短かった。本研究では主旋律に 注意を向ける課題を実施したが, 注意の有無によって ERANの潜時が変動することは確認されていないの で (Loui et al., 2005; Maidhof \& Koelsch, 2011), 注 意が潜時短縮の原因とは考えにくい。一つの可能性と して, 本研究において予期される和音の生起確率が低 かったことが挙げられる。先行研究では試行の半数以 上が予期される和音であるのに対し (Kim et al., 2014; Koelsch et al., 2000, 2002; Koelsch \& Sammler, 2008; Pagès-Portabella \& Toro, 2020), 本研究では $p=.375$ であった。ERANは逸脱和音に対するERPか ら予期される和音に対する $\mathrm{ERP}$ 波形を引算すること によって求める。先行研究では予期される和音に対し て明瞭なP2が生じていたが, 本研究では生じなかっ た。そのため, 差分波形上でERANの後半部が削ら れてしまい，頂点潜時が短くなった可能性がある。

予想外の結果として, バスのみが冕脱したときに大 きな陰性電位が認められた。Koelsch et al. (2000)は, 逸脱和音を意識的に検出するときにはERANに続い てN2bが生じると報告している。しかし，その場合に は, さらにP3(P300) も生じていた。今回はP3に相当 する電位は認められなかったので, この陰性電位が $\mathrm{N} 2 \mathrm{~b}$ といえるかどうかは明らかではない。別の可能性 として,この電位は遅れたERANかもしれない。し かし, 上述のようにERANの潜時が他の条件よりも $100 \mathrm{~ms}$ 近く遅延することは随意的注意の有無を操作 した研究でも確認されていないので (Loui et al., 2005; Maidhof \& Koelsch, 2011), その可能性は低い と考えられる。今後の研究で, その頭皮上分布などを 検討する必要がある。

本研究により, 音楽の統語処理において高音声部の 逸脱が強く影響することが示された。複数の声部があ る場合, 最高声部が逸脱するとより大きなERANが 生じた。今回は, 刺激設定の不備のために検討できな かったが, Kim et al.(2014) と同様にソプラノ声部に 主旋律があるときでも大きなERANが生じるかどう かは今後の研究において確認したい。また, 本研究で 扱ったのは, 特定の声部だけが旋律的進行を示し, 他 の声部は和声的に伴奏するという形態のホモフォニー 系列であった。複数の声部が主旋律や副旋律として並 列しながら和声的に進行するポリフォニー系列で検討 すると, 声部ごとの効果が検討できる。今後ポリフォ 
ニー系列を用いれば，最高声部だけが特異的に影響す るのか, アルトやテノールといった相対的な高音域が 影響するのかが明らかになるだろう。

\section{引用文献}

阿部純一・星野悦子 (1985). メロデイ認知におけ るスキーマ依存性について：音楽熟達者による終 止音導出実験 基礎心理学研究, 4, 1-9.

Bharucha, J., \& Krumhansl, C. L. (1983). The representation of harmonic structure in music: Hierarchies of stability as a function of context. Cognition, 13, 63-102.

Brattico, E., Tervaniemi, M., Näätänen, R., \& Peretz, I. (2006). Musical scale properties are automatically processed in the human auditory cortex. Brain Research, 1117, 162-174.

Fujioka, T., Trainor, L. J., \& Ross, B. (2008). Simultaneous pitches are encoded separately in auditory cortex: An MMNm study. Neuroreport, 19, 361-366.

Fujioka, T., Trainor, L. J., Ross, B., Kakigi, R., \& Pantev, C. (2005). Automatic encoding of polyphonic melodies in musicians and nonmusicians. Journal of Cognitive Neuroscience, 17, 15781592.

橋本 翠 (2011). 音楽的文脈の認知を反映する事象関 連電位に及ぼす注意の効果 広島大学大学院教育 学研究科紀要 第三部 教育人間科学関連領域, $60,225-232$.

星野悦子・阿部純一 (1984). メロデイ認知におけ る “調性感” と終止音導出心理学研究, 54, 344-350.

Kim, C. H., Lee, S., Kim, J. S., Seol, J., Yi, S. W., \& Chung, C. K. (2014). Melody effects on ERANm elicited by harmonic irregularity in musical syntax. Brain Research, 1560, 36-45.

Koelsch, S. (2009). Music-syntactic processing and auditory memory: Similarities and differences between ERAN and MMN. Psychophysiology, 46, 179-190.

Koelsch, S., Gunter, T., Friederici, A. D., \& Schröger, E. (2000). Brain indices of music processing:
"Nonmusicians" are musical. Journal of Cognitive Neuroscience, 12, 520-541.

Koelsch, S., \& Jentschke, S. (2008). Short-term effects of processing musical syntax: An ERP study. Brain Research, 1212, 55-62.

Koelsch, S., \& Jentschke, S. (2010). Differences in electric brain responses to melodies and chords. Journal of Cognitive Neuroscience, 22, 2251-2262.

Koelsch, S., Jentschke, S., Sammler, D., \& Mietchen, D. (2007). Untangling syntactic and sensory processing: An ERP study of music perception. Psychophysiology, 44, 476-490.

Koelsch, S., \& Sammler, D. (2008). Cognitive components of regularity processing in the auditory domain. PLoS ONE, 3, e2650.

Koelsch, S., Schmidt, B. H., \& Kansok, J. (2002) . Effects of musical expertise on the early right anterior negativity: An event-related brain potential study. Psychophysiology, 39, 657-663.

Leino, S., Brattico, E., Tervaniemi, M., \& Vuust, P. (2007). Representation of harmony rules in the human brain: Further evidence from event-related potentials. Brain Research, 1142, 169-177.

Loui, P., Grent, T., Torpey, D., \& Woldorff, M. (2005). Effects of attention on the neural processing of harmonic syntax in Western music. Cognitive Brain Research, 25, 678-687.

Ma, X., Ding, N., Tao, Y., \& Yang, Y. F. (2018). Syntactic complexity and musical proficiency modulate neural processing of non-native music. Neuropsychologia, 121, 164-174.

Maidhof, C., \& Koelsch, S. (2011). Effects of selective attention on syntax processing in music and language. Journal of Cognitive Neuroscience, 23, 2252-2267.

Marie, C., Fujioka, T., Herrington, L., \& Trainor, L. J. (2012). The high-voice superiority effect in polyphonic music is influenced by experience: A comparison of musicians who play soprano-range compared with bass-range instruments. Psychomusicology: Music, Mind, and Brain, 22, 97-104. Meyer, L. B. (1956). Emotion and meaning in music. 
Chicago, IL: University of Chicago Press.

Miranda, R. A., \& Ullman, M. T.(2007). Double dissociation between rules and memory in music: An event-related potential study. Neuroimage, 38, 331-345.

Oldfield, R. C. (1971). The assessment and analysis of handedness: The Edinburgh inventory. Neuropsychologia, 9, 97-113.
Pagès-Portabella, C., \& Toro, J. M. (2020). Dissonant endings of chord progressions elicit a larger ERAN than ambiguous endings in musicians. Psychophysiology, 57, e13476.

Thompson, W. F. (1993). Modeling perceived relationships between melody, harmony, and key. Perception \& Psychophysics, 53, 13-24. 